\title{
Can Machines Teach the Use of the Library?
}

The library at Mt. San Antonio College has experimented with the use of machines in teaching library usage to patrons. Five Videosonic machines were programed to teach general information on the library and to give instruction in the use of periodical indexes and of card catalogs. Controlled study indicated that students who utilized the machines used the library more efficiently and sought services from staff members less frequently than students who did not utilize them. Despite several mechanical limitations, increased use of teaching machines for this purpose is indicated.

T

o give Maximum assistance to the college student as an individual, is becoming increasingly difficult with the greater demands of larger enrollments in the junior colleges. Yet doing so is now more important that at any other time in the history of colleges and universities. It was for this reason that in 1963, the librarians and administration at Mt. San Antonio College began examining more closely the library orientation program.

A variety of traditional techniques combined with innovations had been used and improved each semester to acquaint new students with the library. The tour, illustrated lectures, informal question-and-answer periods over a cup of coffee, special lectures in the classroom, the generalized handbook, the specialized handbook, were but a few of the techniques used. Inevitably, when the time of reckoning arrived as students began actually to use library materials in context, follow-up was necessary. The peak periods appeared always to have

Miss Genung is Dean of Library and Audio Visual Services at Mt. San Antonio College. certain points in common. Repetition, hour after hour, in answering mechanical routine questions on the use of materials, involved much directional and locational information. The same questions requiring the same answers in the explanation of very elementary techniques of library usage became the order of the day.

It appeared that some type of mechanical device might be able to answer the routine questions satisfactorily, and it was for this reason that the possibility of using the teaching machine was explored. A primary question, however, was: What media would be the most effective? Visual, audio, a combination of audio and visual, or audio and visual combined with a response in a multiple choice mode?

The discovery of a unit which appeared to provide all three of these requirements stimulated the request to the Council on Library Resources for a grant to study the performance of a teaching machine in the instruction of library usage. The machine suggested was the "Videosonic," Model 102B500, which was expected to be ready for production by Hughes Aircraft Company, Videosonic Systems Division, in 
the Fall of 1964. The grant which was received made possible a study from July 1,1964 , through June 30,1965 . An unforeseen delay in delivery of the units from the factory until January 1965, however, shortened by one semester the time allotted for the research. The college received the first machines from the production line, bearing serial numbers one through five, barely in time for their use at the beginning of the second semester.

In anticipation of the delivery of the machines, six weeks of intensive programing was undertaken during July and August preceding delivery. The librarians selected to write the script were chosen from the reference department. Each was asked to work alone at the beginning of the project, to incorporate the questions and answers which seemed the most important to his area in the previously established patterns involving assistance to students. Since each librarian represented one of four subject libraries (social sciences, humanities, biological and applied science, physical science and technology) variation in the subject range of questions was possible. Material was then combined, evaluated, and the best suggestions were selected for the final script. As might be expected, there was not unanimity among the librarians because of the differences in subject areas, and two separate scripts were finally written, one for social sciences-humanities, and one for the sciences.

\section{SCOPE OF THE STUdY}

Three areas were selected for the initial study: (1) general directional information in the use of the library; (2) specific routine directions in the use of periodical indexes; and (3) specific directions in the use of the card catalog with emphasis upon subject headings.

It was interesting to observe the framework of criteria which began to evolve as the project progressed. Hav- ing no rule of thumb to follow, it was generally agreed that programs should be kept short and limited to less than twelve minutes per subject. Information should be clear and concise, direct and adaptable to graphic description. Questions and answers should be used via the multiple choice mode at determined intervals. There should be enough variation within the program to hold the interest of the student. Selection of examples should be simple, clear, and relative to subject matter familiar to the student. Opportunity for response to the selection of answers to problems should be interspersed to test the student for his own direction and satisfaction.

With only five Videosonic units available, it was necessary to determine the distribution of the material for the machines. It was decided that one machine would be allocated to the central lobby available to students as they entered the building where they would be most likely to seek general information and assistance. One would be placed in each of the four subject libraries near the index tables and catalogs.

The machine in the central lobby was therefore programed to answer general, directional questions. Those for the separate subject libraries were concerned with the use of periodical indexes and the subject catalog. As was previously mentioned, variations appeared to satisfy two major subject areas, social sciences-humanities, and the sciences.

Tape recordings were made using the question and answer method. Both a man's and a woman's voice were used to give variation. Colored slides were produced by the audio visual librarian to develop the script graphically.

At this point it is appropriate to describe briefly the machines themselves. They are compact, mobile units. The net weight is twenty-three pounds, the width $12 \frac{1}{2}$ inches, the height, $10 \frac{1}{2}$ inches, and 
the depth 18 inches. They can easily be placed on a standing height card catalog reference table near an electrical outlet. A viewing screen in the front of each unit, $8 \frac{1}{12}$ inches $\times 6$ inches, allows the viewer to see the $35 \mathrm{~mm}$ projected slide. The choice of a headset or speaker permits the user to hear the tape recording which is synchronized with the slides in response to a low level tone, recorded on the tape. Slides progress automatically when the switch is turned on, except when the Multiple Choice Mode is used, at which time the user presses the "answer" button from a series of three alternatives. When the correct answer is given, the slides progress in sequence. The Airequipt magazine holds thirty-six $35 \mathrm{~mm}$ slides.

\section{RANGE OF THE EXPERIMENT}

From the time the machines were installed until the completion of the experiment critical observations were recorded. Each staff member was charged with the responsibility of objectively reporting reactions of the students.

The first question of concern was: Would students notice and use the machines? They were used almost immediately after they were placed in the specified areas. Reports indicated that some of the usage stemmed from curiosity at the beginning, but that soon they were

TABLE 1

\begin{tabular}{|c|c|c|}
\hline & $\begin{array}{l}\text { Sought } \\
\text { information } \\
\text { from staff } \\
\text { member for } \\
\text { library } \\
\text { location } \\
\text { (per cent) }\end{array}$ & $\begin{array}{l}\text { Sought } \\
\text { information } \\
\text { for location } \\
\text { of book } \\
\text { (per cent) }\end{array}$ \\
\hline $\begin{array}{l}\text { Students using Video- } \\
\text { sonic }\end{array}$ & 30 & 0 \\
\hline $\begin{array}{l}\text { Students who did not } \\
\text { use Videosonic. }\end{array}$ & 57.1 & 2 \\
\hline $\begin{array}{l}\text { Students who neither } \\
\text { had library lecture } \\
\text { nor Videosonic. }\end{array}$ & 67.7 & 6.4 \\
\hline
\end{tabular}

consulted for information. It appeared that students were less embarrassed to ask a question or reveal their insecurity when they could impersonally consult a mechanical device.

It was expected that after the first six weeks of the semester usage of the unit programed for "general" information would diminish and that this machine might then be programed to the more specialized information relative to the periodical indexes and the card catalog. Although usage declined, there was enough demand to warrant keeping one machine available throughout the semester for general information. In fact, the usage in the lobby the following semester made it necessary to keep at least two machines available. As the librarians began to rely on the use of the programed machines and developed a pattern of referral to them increased usage apparently resulted.

To determine more specifically how effective the machines might be, some rather simple controlled experiments were designed. Three sociology classes were selected. Two classes visited the library for a special lecture in the use of library materials. The Videosonic machines were available for assistance over and above the lecture. The third class neither came to the library for the orientation lecture nor used the Videosonic machines. A quiz consisting of twentyfive questions was designed to test the students and was given to all three classes.

Of the sixty-nine students visiting the library, twenty indicated that they had used the Videosonic machines. A study of the scores of the twenty students in comparison with those who did not use the machines showed that staff assistance was apparently needed less. For example, as is shown in Table 1, in answer to the question, "How did you know in which library you would find the book?" 57.1 per cent of those who indicated 
they did not use Videosonic said that they had asked a library staff member for information, whereas only 30 per cent of those who used Videosonic said that they had consulted library personnel. Of those who neither visited the library during the orientation lecture nor used Videosonic, 67.7 per cent indicated that they had asked a staff member for information. In other words, those who had the opportunity to gain information independently from the lecture and teaching machine apparently used less staff time in completing their assignments, an actual gain of 37.7 per cent.

The staff was very much aware of the fact that a sampling from a study as limited as this may not be conclusive or consistent. An examination of Tables 1-4, however, shows certain patterns of consistency which might encourage the use of such mechanical aids.

Further experimentation and observation will be important in answering many significant questions. For example: Would the machines be more effective placed in a separate room, such as a conference room, rather than close to in- dex tables and the catalog? (One student commented that he would prefer being isolated while using the machines in order to concentrate better). How many machines would be needed in a library for effective use?

Many advantages can be readily detected in the use of a machine which is adaptable to various needs and situations. Programs can be changed to meet new demands by recording new tapes and using different slides, or by changing the sequence to fit the needs. It is not restricted to a specific type of library. Although this study was used in the junior college library, the effectiveness could apply to any institution. It can take the place of, or supplement, more elaborate mechanical systems such as closed-circuit and dial-access computerized systems. Its use is not limited to the library patron. It could also be programed to train staff. For example, library pages could easily be instructed by its use, thus saving staff instruction time for routine directions. It could review staff duties for substitute personnel in cases of absence of regular staff. In

TABLE 2

\begin{tabular}{|c|c|c|c|c|c|c|}
\hline & $\begin{array}{l}\text { Located } \\
\text { information } \\
\text { by use of } \\
\text { author-title } \\
\text { catalog } \\
\text { (per cent) }\end{array}$ & $\begin{array}{l}\text { Located } \\
\text { information } \\
\text { by use of } \\
\text { subject } \\
\text { catalog } \\
\text { (per cent) }\end{array}$ & $\begin{array}{c}\text { Located } \\
\text { book by } \\
\text { asking a } \\
\text { staff } \\
\text { member } \\
\text { (per cent) }\end{array}$ & $\begin{array}{c}\text { Went } \\
\text { directly } \\
\text { to book } \\
\text { stacks } \\
\text { without } \\
\text { consulting } \\
\text { catalog } \\
\text { or staff } \\
\text { (per cent) }\end{array}$ & $\begin{array}{c}\text { Used } \\
\text { location } \\
\text { stamp on } \\
\text { card in } \\
\text { catalog } \\
\text { (per cent) }\end{array}$ & $\begin{array}{l}\text { Did not } \\
\text { locate } \\
\text { (per cent) }\end{array}$ \\
\hline $\begin{array}{l}\text { Students with lecture and } \\
\text { "Videosonic" }\end{array}$ & 50 & 35 & 20 & 5 & 50 & 5 \\
\hline Students with lecture only & 28.5 & 36.7 & 6.1 & 0 & 40.8 & 28.5 \\
\hline $\begin{array}{l}\text { Students who had neither } \\
\text { lecture nor "Video- } \\
\text { sonic" }\end{array}$ & 45.1 & 22.5 & 3.2 & 3.2 & 29 & 35.5 \\
\hline
\end{tabular}

Note: Variability in findings is shown by this chart. The most desirable answer would have been to use the author-title catalog and then to observe location stamp on card. Students using "Videosonic" performed better in using author-title catalog and in observing information stamp ed on card, but in this instance more who had used Videosonic consulted a staff member than did the other groups, as contrasted with information in Table 1, where students using Videosonic consulted the staff members less than did the other groups. 
TABLE 3

\begin{tabular}{c|c|c|c}
\hline \hline & $\begin{array}{c}\text { Searched } \\
\text { catalog } \\
\text { under "T" } \\
\text { (per cent) }\end{array}$ & $\begin{array}{c}\text { Searched } \\
\text { catalog } \\
\text { under "O" } \\
\text { (per cent) }\end{array}$ & $\begin{array}{c}\text { Searched } \\
\text { catalog } \\
\text { under "S" } \\
\text { (per cent) }\end{array}$ \\
\hline $\begin{array}{c}\text { Students with } \\
\text { lecture and } \\
\text { Videosonic }\end{array}$ & 0 & 65 & 15 \\
$\begin{array}{c}\text { Students with } \\
\text { lecture only }\end{array}$ & 18.3 & 55.1 & 22.4 \\
$\begin{array}{c}\text { Students with } \\
\text { neither lec- } \\
\text { ture nor Vid- } \\
\text { eosonic }\end{array}$ & 19.3 & 58.6 & 16.1 \\
\hline
\end{tabular}

NotE: The specific example programed on Videosonic was The old man and the sea. Apparently students using Videosonic were 7-10 per cent more efficient in their performance than were the other groups.

other words, as a time-saving device it can be effective in many situations.

\section{LIMTTATIONS}

There are, however, noticeable mechanical limitations which should be eliminated for better usage. The fact that it is a mechanical device, subject to mechanical failure, is the first hurdle with which to cope. Any device which is expected to perform from the time the library opens until it closes must provide certain features. Its component parts must withstand continuous operation. The Videosonic machines which were used in this experiment were not designed for this type of use, and as a result an electronics technician was continually being called to correct overheating of the unit, worn belts, and jammed programs.

Second, the number of control buttons on the panel necessary for operation frequently caused one of two problems: either they frightened the patron away because they looked too complicated, or they invited the mechanically inclined student to experiment by pressing buttons out of sequence. For a ma- chine as sensitive as this one is to sequential activation, such usage is disastrous. To add to the problem, if the student did not report the fact that as a result of his experimentation the machine was not functioning, other patrons were unable to use it when they wished, and sometimes they would not bother to report either that it was not operating.

These problems can undoubtedly be solved by certain changes in the engineering design of the unit and certainly should be corrected for library use.

A greater problem, and one which will be expensive to correct, is the synchronization of tapes with slides for pattern retrieval. As now designed, each unit is limited to one program. The library patron, on the other hand, is not interested in moving from machine to machine in order to have answers for various subjects. He would like to be able to dial a number as simply as the telephone, on one unit, and receive either a quick answer to a specific question, or a more lengthy explanation for a procedure as occasions arise. What

TABLE 4

\begin{tabular}{c|c|c|c}
\hline \hline & $\begin{array}{c}\text { Percentage } \\
\text { of error } \\
\text { relative } \\
\text { to charge } \\
\text { desk in- } \\
\text { formation } \\
\text { (per cent) }\end{array}$ & $\begin{array}{c}\text { Percentage } \\
\text { of error } \\
\text { relative } \\
\text { to use of } \\
\text { typewriters } \\
\text { (per cent) }\end{array}$ & $\begin{array}{c}\text { Percentage } \\
\text { of error } \\
\text { relative } \\
\text { to use of } \\
\text { storage } \\
\text { lockers } \\
\text { (per cent) }\end{array}$ \\
\hline $\begin{array}{c}\text { Students with } \\
\text { lecture and } \\
\text { Videosonic }\end{array}$ & 0 & 20 & 10 \\
$\begin{array}{c}\text { Students with } \\
\text { lecture only }\end{array}$ & 16.2 & 6.1 & 32.6 \\
$\begin{array}{c}\text { Students with } \\
\text { neither lec- } \\
\text { ture nor Vid- } \\
\text { eosonic . }\end{array}$ & 9.6 & 6.4 & 22.5 \\
\hline
\end{tabular}

NoTE: With respect to general information about services within the building, the percentage of error for those using Videosonic was less with one exception (information regarding use of typewriters) than other groups. 
the profession needs is a miniature, packaged, self-contained dial retrieval unit which can be placed in any part of the library; in other words, an inexpensive substitute for the more costly dial access installations, which will perform in accordance with library needs, and in addition will maintain the features of a teaching machine with the Multiple Choice Mode whereby the patron can evaluate his response in a learning situation.

At present the unit cost of the Videosonic Model 102B500, which runs close to $\$ 700$, will no doubt limit the number that will be obtained in the average library. Again, to be effective, patrons should not have to wait in line for a machine to answer their questions.

In spite of the mechanical limitations described, the principle of involving a mechanical device to relieve staff time of mechanical and repetitious answers is sound. Mt. San Antonio's technician is not discouraged, but rather he believes that experimentation with redesign or modification of this model, or the engineering of a new unit with a slightly different approach, might achieve the desirable results.

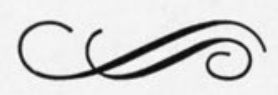

